\title{
Effect of Various Parameters on Methane Emission from the Rumen of HE-Buffalo
}

\author{
Anvesha*, Pramod Kumar and Deepak Kumar \\ Department of Farm Machinery and Power Engineering, College of Technology, \\ Pantnagar-263145, India \\ *Corresponding author
}

\section{A B S T R A C T}

The effect of environment and work conditions on oxygen consumption, methane and carbon dioxide emission from he-buffalo have been studied under a controlled environment using animal treadmill. The environment temperature of the he buffalo was varied in two temperatures $\left(17\right.$ and $\left.37^{\circ} \mathrm{C}\right)$ inside environment controlled chamber. In each temperature he-buffalo was made to exercise with two speeds $(1.5$ and $2.5 \mathrm{~km} / \mathrm{h})$, two treadmill inclinations $\left(0\right.$ and $5^{\circ}$ with the horizontal) and three draughts (no load, 10 and $12 \%$ of bodyweight) for three effective hours. The oxygen consumption of the he-buffalo

\section{Keywords}

Methane, HE Buffalo, Oxygen consumption, Animal Treadmill.

Article Info

Accepted: 17 September 2017 Available Online: 10 November 2017 was observed to be increasing with the increase in temperature, speed, inclination of treadmill and duration of exercise. The typical minimum percent increase in oxygen consumption during the study was found to be $11.09 \%$ at $17^{\circ} \mathrm{C}$ temperature and $45 \%$ humidity, $0^{\circ}$ inclination of treadmill, speed of $1.5 \mathrm{~km} / \mathrm{h}$ and no load condition whereas the maximum percent increase was recorded as $639.86 \%$ at $37^{\circ} \mathrm{C}$ temperature and $45 \%$ humidity, $5^{\circ}$ inclination of treadmill, speed of $2.5 \mathrm{~km} / \mathrm{h}$ and $12 \%$ draught. The methane concentration in exiled of he-buffalo also showed an increasing trend with the increase in temperature, speed, inclination, draught and duration of exercise. The typical minimum increase in percentage of methane concentration was found to be $9.66 \%$ at $17^{\circ} \mathrm{C}$ temperature and $45 \%$ humidity, $1.5 \mathrm{~km} / \mathrm{h}$ speed, and $5^{\circ}$ inclination of treadmill, no load condition. The maximum percent increase of methane concentration was $67.51 \%$ in and $17^{\circ} \mathrm{C}$ temperature and $45 \%$ humidity, $2.5 \mathrm{~km} / \mathrm{h}$ speed, $5^{\circ}$ inclination of treadmill, $12 \%$ draught. Carbon dioxide concentration in the exiled gas decreased with the increase in temperature, speed, draught and duration of exercise. The maximum percent change in carbon dioxide concentration was found to be $5.48 \%$ at $17^{\circ} \mathrm{C}$ temperature and $45 \%$ humidity, $2.5 \mathrm{~km} / \mathrm{h}$ speed, $5^{\circ}$ inclination of treadmill, $12 \%$ draught and minimum percent change in carbon dioxide concentration was found to be $0.77 \%$, at $17^{\circ} \mathrm{C}$ temperature and $45 \%$ humidity, $1.5 \mathrm{~km} / \mathrm{h}$ speed, $5^{\circ}$ inclination of treadmill, no load condition.

\section{Introduction}

It is well documented that global atmospheric abundance of methane is increasing. Methane is one of the most important greenhouse gases in the atmosphere. Methane affects not only the energy balance on earth because of its radiative forcing properties but also ozone, hydroxyl radicals, carbon monoxide concentrations, stratospheric chlorine, ozone chemistry and climate change (Harper et al., 1999). Methane is released into the atmosphere both by natural for example wetlands and anthropogenic sources which 
include rice fields, biomass, ruminants, etc. Agriculture is one of the activities that has the highest anthropogenic emissions of greenhouse gases. It is estimated that agriculture contributes to the anthropogenic emissions of carbon dioxide $\left(\mathrm{CO}_{2}\right)$, methane $\left(\mathrm{CH}_{4}\right)$ and nitrous oxide $\left(\mathrm{N}_{2} \mathrm{O}\right)$ with about 21 25, 60 and 65-80\% respectively (Moss et al., 2000). At the same time, agriculture is the basis for human survival and cannot be replaced. Worldwide initiatives such as Kyoto protocol demand that these emissions be reduced or at least prevented from further increase (Howden and Reyenga, 1999).Sixtyone per cent of the emissions come from fossil-fuel combustion and $28 \%$ from agricultural activities such as livestock rearing, manure, management, rice cultivation, burning of crop residues, etc.

In the agriculture sector, livestock rearing is the major cause of emission and accounts for $78 \%$ of total methane emission from the agriculture sector and about $50 \%$ of methane emission from all sectors (NATCOM report, Ministry of Environment and Forests, 2004). Methane emissions from livestock makes up 18 per cent of total world greenhouse gas emissions and the net contribution of enteric fermentation to greenhouse gas is 5\% (IPCC, 2006). The main source of methane emission from livestock

\section{Enteric fermentation}

This is responsible for high emission of methane from ruminants. These animals possess rumen or fore stomach, which allows them to digest large quantities of cellulose and other roughages found in plant material.

A small fraction of symbiotic microorganisms $(3-10 \%)$ is methanogenic bacteria, which produce methane while removing hydrogen from the rumen. Methane is released mainly through eructation and normal respiration and a small quantity as flatus (Swamy et al., 2006). Ruminant livestock can produce 250 to 500 L of methane per day (Johnson and Johnson 1995)

\section{Manure management}

Livestock manure is principally composed of organic material. When this organic material decomposes in anaerobic environment, methanogenic bacteria produce methane. When manure is stored or treated as a liquid (e.g. in lagoons, ponds, tanks or pits), it tends to decompose anaerobically and produce a significant quantity of methane. When manure is handled as a solid (e.g. in stacks or pits) or deposited on pastures and rangelands, it tends to decompose aerobically and little or no methane is produced.

\section{Materials and Methods}

Description of environmental controlled chamber in which investigation was carried out and the instruments used with the chamber, Specifications of the treadmill, methods of adaptation and parameters.

A room in which the temperature and humidity are controlled independent of each other and kept constant within minimum differences at any particular level for a certain period of time is called an Environment controlled chamber or a Psychometric chamber such that the effect of temperature and various other factors on physiological functions of the animals could be studied.

The psychometric chamber was developed in the Department of Farm Machinery and Power Engineering, College of Technology, G.B. Pant University of Agriculture and Technology, Pantnagar. It mainly consists of split type air conditioners, heat convectors, controller for temperature and humidity and humidifiers etc. which are described as under. 
The overall dimensions of the chamber such as length, width and height were $8.18 \mathrm{~m} \times$ $4.20 \mathrm{~m} \times 3.65 \mathrm{~m}$ respectively. The controlled chamber was developed with the use of aluminum frame of different sections, $12 \mathrm{~mm}$ thick nova pan, $5 \mathrm{~mm}$ thick plain glass. The roof of the chamber was fabricated with 12 $\mathrm{mm}$ thick gypsum tiles. The chamber consisted of two sliding doors (one bigger size $2580 \times 950 \mathrm{~mm}$ and another smaller size $2210 \times 850 \mathrm{~mm}$ ). The bigger door was used to let animal inside the chamber and the smaller door was used for the monitoring of the experiments (Figs. 1 and 2). The other appliances used are animal treadmill, six electric fan of 58 watt each, spirometer, three air conditions, digital temperature indicator, twelve fluorescent tube light of 48 watt each, two person inside for handling animal and one Buffalo in controlled chamber for experiment. The experiments were carried out in the psychometric chamber on animal treadmill on he-buffalo to study various responses of different working conditions on the factors like methane emission, carbon dioxide emission and the oxygen consumption by the he-buffalo.

\section{Experimental methodology}

The temperature and humidity of the environmental controlled chamber was maintained prior to start of the experiment with the help of instruments mentioned above. The treadmill was calibrated before the start of the experiment. The he-buffalo was allowed to climb up on the animal treadmill followed by harnessing with the help of Pant adjustable single animal collar harness and another harness was connected to the hanging weight type loading arrangement with Ushaped pipe frame where loads could be placed (Fig. 2). The experiments were carried out in two room temperatures $\left(22^{\circ} \mathrm{C}\right.$ and $40^{\circ} \mathrm{C}$ and $45 \%$ humidity) and at three inclinations, with three draughts as mentioned above. The two he-buffalo were exercised on treadmill in the morning 9:00 am and evening 2:30 pm alternatively, for a period of three hours or up to the he-buffalo reached a stage of fatigue (fatigues score card was referred to diagnose). The oxygen consumption was noted at the end of every hour of exercise, for the analysis of methane and carbon dioxide production the exhaled gas samples were also taken on hourly basis. At the time of experiment the temperature and humidity were kept constant inside the chamber.

\section{Methane and carbon dioxide emission}

To analyze the methane and carbon dioxide produced from the rumen of the he-buffalo the exhaled air by the he-buffalo were collected in a leak proof bag also known as Douglas bag. The exhaled air was collected by putting an air tight face mask on the mouth of he-buffalo which was connected with the Douglas bag with $22 \mathrm{~mm}$ diameter anti-static corrugated rubber tube and a three way non return valve, whose one end was connected to the face mask and the other end was connected to the Douglas bag to collect the exhaled air. The third end of the three way valve was open to fresh air to be inspired by the he-buffalo. The isometric view of three way air valve was developed using Pro-E 2014 computer software and is shown in Figure 2 with the help of $20 \mathrm{~mL}$ disposable syringes samples were taken for analysis. The syringe was made leak proof with the rubber tube of the same size of syringe opening with tying knot in it. The collected samples were analyzed with the help of Gas Chromatograph- Flame Ionization Detector in CMERI, Ludhiana.

\section{Oxygen consumption}

Oxygen consumption is the volume of oxygen consumed per minute by the organism. The spirometer is an instrument used to measure 
the respired volumes and oxygen consumption with closed circuitry (Fig. A). A Benedict Roth Spirometer was used to determine the oxygen consumption of hebuffalo. A Benedict Roth mainly consists of a bell for collection of pure oxygen (provided separately through the oxygen cylinder to the spirometer), a counter weight attached with the bell to balance oxygen level, base, recording drum on which recording graph is fixed, with four speeds viz. 0. 2, 0.4 and 20 $\mathrm{mm} / \mathrm{sec}$ and a pointer attached with counter weight which marks on the chart paper. For the measurement of oxygen consumption of he-buffalo the face mask was put on the mouth of the he-buffalo and was connected to the spirometer which was kept under working condition i.e. the bell of the spirometer was filled with oxygen. As the he-buffalo respired through the face mask and consumed the oxygen filled inside the bell, the level of the bell lowered down and the pointer attached to the bell recorded the volume of oxygen fetched from the bell on the graph on the rotating drum. The graph obtained with the experiment is known as kymograph and was analyzed for oxygen consumption (1/min).

\section{Results and Discussion}

The responses of he-buffalo were observed in order to estimate the methane and carbon dioxide concentration in exiled air and total oxygen consumed during the exercise on treadmill. The he-buffalo weighing $600 \mathrm{~kg}$ was exercised on treadmill at two levels of speeds, temperatures and inclination and three levels of draughts for a period of three hours or the time till the buffalo reached a stage of fatigue under different test conditions.

Effect of influencing factors i.e. temperature, speed, inclination of treadmill, draught and duration of exercise on the responses i.e. oxygen consumption, methane and carbon dioxide concentration in the exiled air of he- buffalo was determined and statistically analysed.

\section{Effect of influencing factors on oxygen consumption of he-buffalo}

Table 1 represents the average oxygen consumption recorded during the investigation. The variation in oxygen consumption of he-buffalo during exercise on the animal treadmill under various controlled environments and treadmill settings. It can be contemplated from Table 1 that the oxygen consumption of the test draught he-buffalo at $17^{\circ} \mathrm{C}$ and $45 \%$ humidity with $0^{\circ}$ inclination of the animal treadmill at $1.5 \mathrm{~km} / \mathrm{h}$ speed of treadmill, increased with the duration of exercise from initial value to $12.21,32.21$ and $60.71 \%$ for 0 (no load), 10 and $12 \%$ draught respectively after 3 hours of treadmill exercise.

It is shown from the Table 1 the buffalo's rate of oxygen consumption increases with increase in draught at all combinations of temperature, speeds, inclination of treadmill and duration of exercise. It was also perceived that the requirement of oxygen in higher environment temperature \&humidity was found to be higher as compared to lower temperature \&humidity. The maximum increment in oxygen consumption observed in the present study was found to be $432 \%$ $\left(17^{\circ} \mathrm{C}\right.$ temperature and $45 \%$ humidity, $5^{\circ}$ inclination of treadmill, $2.5 \mathrm{~km} / \mathrm{h}$ and $12 \%$ draught. The rise in oxygen consumption paralleled the increase in speed, inclination, draught, temperature and duration of exercise, which was in agreement with Upadhyay and Agarwal (1997), who reported the increase of $39.72 \%$ in oxygen consumption with increase in temperature, inclination, speed and draughts during treadmill exercises in bullocks and Das et al., (1999) also reported that there was an increase in various gaseous parameters with exposure of the cattle to heat. 
The relation between oxygen consumption, duration of exercise at different level of draughts with various levels of speed, treadmill inclination from the horizontal and temperature is depicted by Figures 3 to 4 . The figures show that there is an increasing trend in oxygen consumption from the initial phase $(0 \mathrm{~h})$ till the end of exercise. Figure 4 presents the average relation between various parameters and oxygen consumption.

\section{Statistical analysis of oxygen consumption}

Table 1 Shows the effect of influencing factors at linear and interaction levels. It is revealed from the table that the effects on oxygen consumption of all influencing factor at both linear and interactive were highly significant at $1 \%$ level of significance $(p<0.01)$, as their Fcal was greater than $F_{\text {tab }}$.

The effect of individual influencing factors (temperature, speed, inclination of treadmill, draught and duration of exercise) on oxygen consumption was computed using sequential sum of square and was shown on Table B. It can be seen from the table that all the influencing factors were highly significantly at $1 \%$ level of significance $(\mathrm{p}<0.01)$.

\section{Effect of influencing factors on methane concentration in exiled gas of he-buffalo}

The exiled gas samples were collected for two levels of temperatures, speeds, inclinations of treadmill and three levels of draughts and four levels of duration of exercise were analyzed with flame ionization detector of gas chromatograph. The hourly estimates of methane concentration in the exiled gas with replications for 3 hour treadmill exercises have been showed in table 2 and 3 . Table 2 and 3 shows Methane concentration in the exiled gas of he-buffaloes during exercise on treadmill under controlled environmental conditions.

Table.1 Average oxygen consumption ( $1 / \mathrm{min})$ of draught buffalo on treadmill exercise under controlled condition at $17^{\circ} \mathrm{C}$ and $45 \%$ humidity

\begin{tabular}{|c|c|c|c|c|c|c|c|}
\hline \multirow{2}{*}{$\begin{array}{l}\text { Speed, } \\
\text { km/h }\end{array}$} & \multirow{2}{*}{$\begin{array}{l}\text { Inclination, }{ }^{\circ} \\
\text { from } \\
\text { Horizontal }\end{array}$} & \multirow{2}{*}{$\begin{array}{l}\text { Draught, } \\
\text { \% BW }\end{array}$} & \multicolumn{4}{|c|}{ Duration of exercise, $h$} & \multirow[t]{2}{*}{$\%$ increase } \\
\hline & & & 0 & $1 \mathrm{~h}$ & $2 \mathrm{~h}$ & $3 \mathrm{~h}$ & \\
\hline \multirow[t]{7}{*}{1.5} & \multirow[t]{3}{*}{0} & No load & 8.90 & 9.00 & 9.60 & 9.99 & 12.21 \\
\hline & & $10 \%$ & 8.42 & 9.90 & 10.75 & 11.13 & 32.21 \\
\hline & & $12 \%$ & 8.70 & 10.62 & 12.79 & 13.98 & 60.71 \\
\hline & \multirow[t]{3}{*}{5} & No load & 8.57 & 9.57 & 13.62 & 18.60 & 116.99 \\
\hline & & $10 \%$ & 8.69 & 13.67 & 21.10 & 25.62 & 194.83 \\
\hline & & $12 \%$ & 8.44 & 18.78 & 29.97 & 40.91 & 384.72 \\
\hline & 0 & No load & 8.85 & 10.06 & 11.55 & 12.02 & 35.76 \\
\hline \multirow[t]{5}{*}{2.5} & & $10 \%$ & 8.46 & 14.97 & 16.72 & 18.69 & 120.91 \\
\hline & & $12 \%$ & 8.97 & 17.59 & 21.34 & 26.96 & 200.54 \\
\hline & \multirow[t]{3}{*}{5} & No load & 9.00 & 17.02 & 26.69 & 32.98 & 266.47 \\
\hline & & $10 \%$ & 8.79 & 20.99 & 21.50 & 36.00 & 309.57 \\
\hline & & $12 \%$ & 8.39 & 27.66 & 30.50 & 44.72 & 432.96 \\
\hline
\end{tabular}


Table.2 Methane concentration (\%) in the exiled gas of draught buffalo on treadmill exercise under controlled condition at $17^{\circ} \mathrm{C}$ and $45 \%$ humidity

\begin{tabular}{|c|c|c|c|c|c|c|c|}
\hline \multirow{2}{*}{$\begin{array}{l}\text { Speed, } \\
\text { km/h }\end{array}$} & \multirow{2}{*}{$\begin{array}{l}\text { Inclination, } \\
\text { from } \\
\text { Horizontal }\end{array}$} & \multirow{2}{*}{$\begin{array}{l}{ }^{\circ} \text { Draught, } \\
\% \mathrm{BW}\end{array}$} & \multicolumn{4}{|c|}{ Duration of exercise, $h$} & \multirow[t]{2}{*}{$\%$ increase } \\
\hline & & & 0 & $1 \mathrm{~h}$ & $2 \mathrm{~h}$ & $3 \mathrm{~h}$ & \\
\hline \multirow[t]{6}{*}{1.5} & 0 & No load & 6.017 & 6.09 & 6.85 & 6.99 & 16.16 \\
\hline & & $10 \%$ & 7.26 & 8.09 & 8.96 & 9.29 & 27.96 \\
\hline & & $12 \%$ & 7.32 & 7.98 & 9.79 & 10.88 & 48.63 \\
\hline & 5 & No load & 7.35 & 7.39 & 7.9 & 8.06 & 9.66 \\
\hline & & $10 \%$ & 7.29 & 8.53 & 10.01 & 10.51 & 44.17 \\
\hline & & $12 \%$ & 7.66 & 8.77 & 10.77 & 10.98 & 43.34 \\
\hline \multirow[t]{6}{*}{2.5} & 0 & No load & 7.72 & 7.93 & 9.03 & 9.87 & 27.85 \\
\hline & & $10 \%$ & 7.19 & 8.99 & 10.75 & 11.58 & 61.06 \\
\hline & & $12 \%$ & 7.66 & 9.27 & 11.97 & 12.41 & 62.01 \\
\hline & 5 & No load & 7.79 & 8.53 & 10.52 & 10.63 & 36.46 \\
\hline & & $10 \%$ & 7.75 & 9.87 & 11.21 & 11.97 & 54.45 \\
\hline & & $12 \%$ & 7.51 & 10.75 & 12.09 & 12.58 & 67.51 \\
\hline
\end{tabular}

Table.3 Methane concentration (\%) in the exiled gas of draught buffalo on treadmill exercise under controlled condition at $37^{\circ} \mathrm{C}$ and $45 \%$ humidity

\begin{tabular}{|c|c|c|c|c|c|c|c|}
\hline \multirow{2}{*}{$\begin{array}{l}\text { Speed, } \\
\text { km/h }\end{array}$} & \multirow{2}{*}{$\begin{array}{l}\text { Inclination, } \\
\text { from } \\
\text { Horizontal }\end{array}$} & \multirow{2}{*}{$\begin{array}{l}\text { Draught, } \\
\% \mathbf{B W}\end{array}$} & \multicolumn{4}{|c|}{ Duration of exercise, $h$} & \multirow[t]{2}{*}{$\%$ increase } \\
\hline & & & 0 & $1 \mathrm{~h}$ & $2 \mathrm{~h}$ & $3 h$ & \\
\hline \multirow[t]{6}{*}{1.5} & 0 & No load & 8.91 & 9.23 & 9.51 & 9.79 & 9.88 \\
\hline & & $10 \%$ & 9.25 & 10.36 & 11.22 & 11.26 & 21.73 \\
\hline & & $12 \%$ & 9.29 & 10.94 & 11.39 & 11.78 & 26.80 \\
\hline & 5 & No load & 9.22 & 10.06 & 10.27 & 10.24 & 11.06 \\
\hline & & $10 \%$ & 9.81 & 11.63 & 11.78 & 12.69 & 29.36 \\
\hline & & $12 \%$ & 9.62 & 11.77 & 12.28 & 12.93 & 34.41 \\
\hline \multirow[t]{6}{*}{2.5} & 0 & No load & 9.48 & 10.00 & 10.76 & 10.99 & 15.93 \\
\hline & & $10 \%$ & 9.95 & 11.63 & 12.63 & 12.81 & 28.74 \\
\hline & & $12 \%$ & 9.73 & 12.23 & 12.72 & 12.91 & 32.68 \\
\hline & 5 & No load & 9.26 & 10.68 & 11.34 & 11.69 & 26.24 \\
\hline & & $10 \%$ & 9.87 & 12.27 & 12.31 & 12.38 & 25.43 \\
\hline & & $12 \%$ & 9.82 & 12.33 & 12.59 & 12.72 & 29.53 \\
\hline
\end{tabular}


Table.4 Carbon dioxide concentration (\%) in the exiled gas of draught buffalo on treadmill exercise under controlled condition at $17^{\circ} \mathrm{C}$ and $45 \%$ humidity

\begin{tabular}{|c|c|c|c|c|c|c|c|}
\hline \multirow{2}{*}{$\begin{array}{l}\text { Speed, } \\
\text { km/h }\end{array}$} & \multirow{2}{*}{$\begin{array}{l}\text { Inclination, } \\
\text { ofom } \\
\text { Horizontal }\end{array}$} & \multirow{2}{*}{$\begin{array}{l}\text { Draught, } \\
\% \mathrm{BW}\end{array}$} & \multicolumn{4}{|c|}{ Duration of exercise, $h$} & \multirow[t]{2}{*}{$\%$ Decrease } \\
\hline & & & 0 & $1 \mathrm{~h}$ & $2 \mathrm{~h}$ & $3 \mathrm{~h}$ & \\
\hline \multirow[t]{6}{*}{1.5} & 0 & No load & 93.98 & 93.41 & 93.45 & 93.11 & 0.93 \\
\hline & & $10 \%$ & 92.74 & 91.91 & 91.04 & 90.71 & 2.19 \\
\hline & & $12 \%$ & 92.68 & 92.02 & 90.21 & 89.12 & 3.84 \\
\hline & 5 & No load & 92.65 & 92.61 & 92.1 & 91.94 & 0.77 \\
\hline & & $10 \%$ & 92.71 & 91.47 & 89.99 & 89.49 & 3.47 \\
\hline & & $12 \%$ & 92.34 & 91.23 & 89.23 & 89.02 & 3.60 \\
\hline \multirow[t]{6}{*}{2.5} & 0 & No load & 92.28 & 92.07 & 90.97 & 90.13 & 2.33 \\
\hline & & $10 \%$ & 92.81 & 91.01 & 89.25 & 88.42 & 4.73 \\
\hline & & $12 \%$ & 92.34 & 90.73 & 88.03 & 87.59 & 5.14 \\
\hline & 5 & No load & 92.21 & 91.47 & 89.48 & 89.37 & 3.08 \\
\hline & & $10 \%$ & 92.25 & 90.13 & 88.79 & 88.03 & 4.57 \\
\hline & & $12 \%$ & 92.49 & 89.25 & 87.91 & 87.42 & 5.48 \\
\hline
\end{tabular}

Table.5 Carbon dioxide concentration (\%) in the exiled gas of draught buffalo on treadmill exercise under controlled condition at $37^{\circ} \mathrm{C}$ and $45 \%$ humidity

\begin{tabular}{|c|c|c|c|c|c|c|c|}
\hline \multirow{2}{*}{$\begin{array}{l}\text { Speed, } \\
\text { km/h }\end{array}$} & \multirow{2}{*}{$\begin{array}{l}\text { Inclination, } \\
\circ \quad \text { from } \\
\text { Horizontal }\end{array}$} & \multirow{2}{*}{$\begin{array}{l}\text { Draught, } \\
\% \mathrm{BW}\end{array}$} & \multicolumn{4}{|c|}{ Duration of exercise, $h$} & \multirow[t]{2}{*}{$\%$ Decrease } \\
\hline & & & 0 & $1 \mathrm{~h}$ & $2 \mathrm{~h}$ & $3 \mathrm{~h}$ & \\
\hline \multirow[t]{6}{*}{1.5} & 0 & No load & 91.09 & 90.77 & 90.49 & 90.21 & 0.97 \\
\hline & & $10 \%$ & 90.75 & 89.64 & 88.78 & 88.74 & 2.21 \\
\hline & & $12 \%$ & 90.71 & 89.06 & 88.61 & 88.22 & 2.75 \\
\hline & 5 & No load & 90.78 & 89.94 & 89.73 & 89.76 & 1.12 \\
\hline & & $10 \%$ & 90.19 & 88.37 & 88.22 & 87.31 & 3.19 \\
\hline & & $12 \%$ & 90.38 & 88.23 & 87.72 & 87.07 & 3.66 \\
\hline \multirow[t]{6}{*}{2.5} & 0 & No load & 90.52 & 90.00 & 89.24 & 89.01 & 1.67 \\
\hline & & $10 \%$ & 90.05 & 88.37 & 87.37 & 87.19 & 3.18 \\
\hline & & $12 \%$ & 90.27 & 87.77 & 87.28 & 87.09 & 3.52 \\
\hline & 5 & No load & 90.74 & 89.32 & 88.66 & 88.31 & 2.68 \\
\hline & & $10 \%$ & 90.13 & 87.73 & 87.69 & 87.62 & 2.78 \\
\hline & & $12 \%$ & 90.18 & 87.67 & 87.41 & 87.28 & 3.22 \\
\hline
\end{tabular}

Table.A ANOVA for oxygen consumption

\begin{tabular}{ccccc}
\hline Source & DF & SS & MS & F cal \\
Model & 15 & 20824 & 1388.26 & $48.85^{* * *}$ \\
Linear & 5 & 14700.18 & 2940 & $103.46^{* * *}$ \\
Interactive & 10 & 3440.02 & 344 & $12.10^{* * *}$ \\
Error & 80 & 2273.3 & 28.41 & \\
Total & 95 & 23097.3 & & \\
\hline
\end{tabular}

$* * *, * * *$ Significant at 1,5 and $10 \%$ level of significance respectively

$\mathrm{F}_{\text {tab }}(15,80)=2.27 ; \mathrm{F}_{\text {tab }}(5,80)=3.25 ; \mathrm{F}_{\text {tab }}(10,80)=2.55(1 \%)$

$\mathrm{F}_{\text {tab }}(15,80)=1.79 ; \mathrm{F}_{\text {tab }}(5,80)=2.32 ; \mathrm{F}_{\text {tab }}(10,80)=1.95(5 \%)$

$\mathrm{F}_{\text {tab }}(15,80)=1.57 ; \mathrm{F}_{\text {tab }}(5,80)=1.92 ; \mathrm{F}_{\text {tab }}(10,80)=1.679(10 \%)$ 
Table.B Total effect of individual parameters on oxygen consumption

\begin{tabular}{ccccc}
\hline Source & DF & SS & MSS & Fcal \\
Model & 15 & 20824 & 1388.26 & $48.85^{* * *}$ \\
Temperature (A) & 5 & 5169.05 & 1033.81 & $36.38^{* * *}$ \\
Speed (B) & 5 & 917.39 & 183.47 & $6.45^{* * *}$ \\
Inclination (C) & 5 & 1925.24 & 385.05 & $13.55^{* * *}$ \\
Draught (D) & 5 & 3331.12 & 666.22 & $23.44^{* * *}$ \\
Duration of exercise (E) & 5 & 10237.42 & 2047.48 & $72.05^{* * *}$ \\
ERROR & 80 & 2273.3 & 28.41 & \\
TOTAL & 95 & 23097.3 & & \\
\hline
\end{tabular}

$* * *, * *$ and $*$ Significant at 1,5 and $10 \%$ level of significance respectively

$\mathrm{F}_{\mathrm{tab}}(15,80)=2.27 ; \mathrm{F}_{\mathrm{tab}}(5,80)=3.25(1 \%)$;

$\mathrm{F}_{\text {tab }}(15,80)=1.79 ; \mathrm{F}_{\text {tab }}(5,80)=2.32(5 \%)$;

$\mathrm{F}_{\mathrm{tab}}(15,80)=1.57 ; \mathrm{F}_{\mathrm{tab}}(5,80)=1.92(10 \%)$

Table.C ANOVA for methane concentration in exiled gas

\begin{tabular}{ccccc}
\hline SOURCE & DF & SS & MS & F-VALUE \\
Model & 15 & 295.33 & 19.68 & $82.70^{* * *}$ \\
Linear & 5 & 252.45 & 50.49 & $212.08^{* * * *}$ \\
Interactive & 10 & 22.30 & 2.23 & $9.367^{* * *}$ \\
Residual error & 80 & 19.045 & 0.24 & \\
Total & 95 & 314.37 & & \\
\hline
\end{tabular}

***,***, Significant at 1,5 and $10 \%$ level of significance respectively

$\mathrm{F}_{\mathrm{tab}}(15,80)=2.27 ; \mathrm{F}_{\mathrm{tab}}(5,80)=3.25 ; \mathrm{F}_{\mathrm{tab}}(10,80)=6.719(1 \%)$

$\mathrm{F}_{\text {tab }}(15,80)=1.79 ; \mathrm{F}_{\text {tab }}(5,80)=2.32 ; \mathrm{F}_{\text {tab }}(10,80)=1.92(5 \%)$

$\mathrm{F}_{\text {tab }}(15,80)=2.55 ; \mathrm{F}_{\text {tab }}(5,80)=1.95 ; \mathrm{F}_{\text {tab }}(10,80)=1.67(10 \%)$

Table.D Total effect of individual parameters on methane concentration in exiled gas

\begin{tabular}{ccccc}
\hline Source & DF & SS & MSS & Fcal \\
Model & 15 & 295.33 & 19.68 & $82.70^{* * *}$ \\
Temperature (A) & 5 & 94.25 & 18.85 & $79.18^{* * *}$ \\
Speed (B) & 5 & 39.69 & 7.93 & $33.34^{* * *}$ \\
Inclination (C) & 5 & 9.83 & 1.96 & $8.26^{* * *}$ \\
Draught (D) & 5 & 57.87 & 11.57 & $48.62^{* * *}$ \\
Duration of exercise (E) & 5 & 95.36 & 19.07 & $80.13^{* * *}$ \\
Error & 80 & 19.04 & 0.23 & \\
Total & 95 & 314.37 & & \\
\hline
\end{tabular}

$* * *, * *$ and $*$ Significant at 1,5 and $10 \%$ level of significance respectively

$\mathrm{F}_{\text {tab }}(15,80)=2.27 ; \mathrm{F}_{\text {tab }}(5,80)=3.25(1 \%)$;

$\mathrm{F}_{\mathrm{tab}}(15,80)=1.79 ; \mathrm{F}_{\mathrm{tab}}(5,80)=2.32(5 \%)$;

$\mathrm{F}_{\text {tab }}(15,80)=1.57 ; \mathrm{F}_{\text {tab }}(5,80)=1.92(10 \%)$ 
Table.E ANOVA for carbon dioxide concentration in the exiled gas

\begin{tabular}{ccccc}
\hline SOURCE & DF & SS & MS & F-VALUE \\
Model & 15 & 294.72 & 19.64 & $75.18^{* * *}$ \\
Linear & 5 & 250.92 & 50.18 & $192.03^{* * *}$ \\
Interactive & 10 & 23.56 & 2.35 & $9.01^{* * * *}$ \\
Residual error & 80 & 20.91 & 0.26 & \\
Total & 95 & 315.63 & & \\
\hline
\end{tabular}

***, **** Significant at 1,5 and $10 \%$ level of significance respectively

$\mathrm{F}_{\mathrm{tab}}(15,80)=2.27 ; \mathrm{F}_{\mathrm{tab}}(5,80)=3.25 ; \mathrm{F}_{\mathrm{tab}}(10,80)=6.719(1 \%)$

$\mathrm{F}_{\text {tab }}(15,80)=1.79 ; \mathrm{F}_{\text {tab }}(5,80)=2.32 ; \mathrm{F}_{\text {tab }}(10,80)=1.92(5 \%)$

$\mathrm{F}_{\text {tab }}(15,80)=2.55 ; \mathrm{F}_{\text {tab }}(5,80)=1.95 ; \mathrm{F}_{\mathrm{tab}}(10,80)=1.67(10 \%)$

Table.F Total effect of individual parameters on carbon dioxide concentration in the exiled gas

\begin{tabular}{ccccc}
\hline Source & DF & SS & MSS & Fcal \\
Model & 15 & 294.72 & 19.64 & $75.18^{* * *}$ \\
Temperature (A) & 5 & 96.46 & 19.29 & $73.82^{* * *}$ \\
Speed (B) & 5 & 41.23 & 8.24 & $31.55^{* * *}$ \\
Inclination (C) & 5 & 9.35 & 1.87 & $7.16^{* * *}$ \\
Draught (D) & 5 & 56.92 & 11.38 & $43.56^{* * *}$ \\
Duration of exercise (E) & 5 & 94.06 & 18.81 & $71.98^{* * *}$ \\
Error & 80 & 20.90 & 0.26 & \\
Total & 95 & 315.63 & & \\
\hline
\end{tabular}

***, ** and * Significant at 1,5 and $10 \%$ level of significance respectively

$\mathrm{F}_{\text {tab }}(15,80)=2.27 ; \mathrm{F}_{\mathrm{tab}}(5,80)=3.25(1 \%)$;

$\mathrm{F}_{\mathrm{tab}}(15,80)=1.79 ; \mathrm{F}_{\mathrm{tab}}(5,80)=2.32(5 \%)$;

$\mathrm{F}_{\text {tab }}(15,80)=1.57 ; \mathrm{F}_{\text {tab }}(5,80)=1.92(10 \%)$

\section{Experimental variables}

\section{Independent variables}

Draught equivalent to \% body No load ( $0 \%$ of body weight), $10 \%$ of body weight (60kgf) weight of the he-buffalo at $\& 12 \%$ of body weight (72kgf).

Speed

a) $1.5 \mathrm{~km} / \mathrm{h}$, b) $2.5 \mathrm{~km} / \mathrm{h}$

Inclination of treadmill

a) $0^{\circ}$ from the horizontal, b) $5^{\circ}$ from the horizontal

Temperature, ${ }^{\circ} \mathrm{C}$

a) $17^{\circ} \mathrm{C}$ and $45 \%$ humidity, b) $37^{\circ} \mathrm{C}$ and $45 \%$ humidity

Duration of exercise a) $0 \mathrm{~h}, \mathrm{~b}) 1 \mathrm{~h}, \mathrm{c}) 2 \mathrm{~h}, \mathrm{~d}) 3 \mathrm{~h}$,

\section{Dependent variables}

Methane production (\%), Carbon dioxide production (\%), Oxygen consumption (1/min.)

\section{Fixed variables}

Green fodder (barseem), Wheat bhusa ad lib. 
$19^{\text {th }}$ Livestock census-2012, All India Report

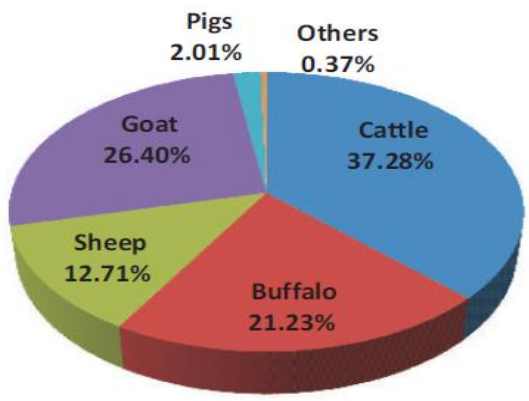

Fig.1 View of buffallo excersise in environment controlled chamber

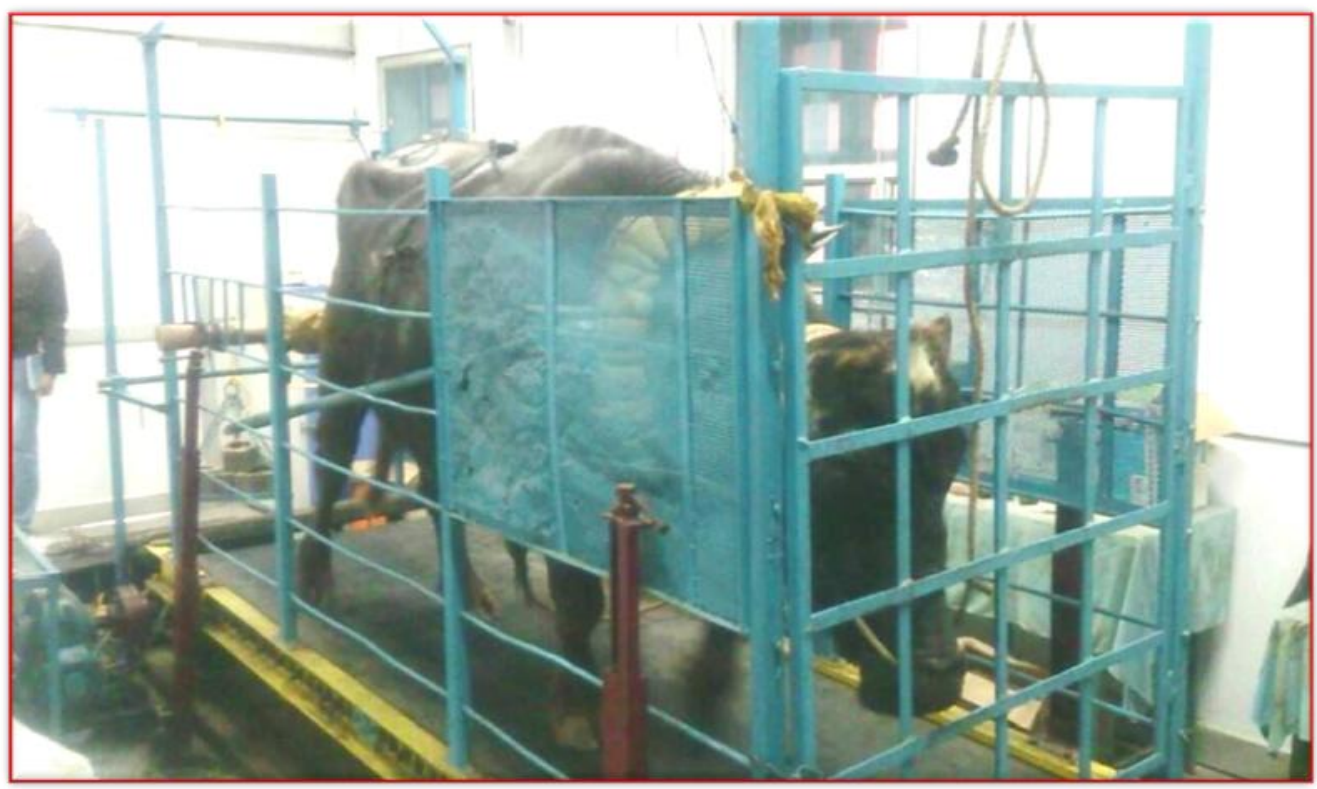

Fig.2 Three way air valve and Pant adjustable collar harness
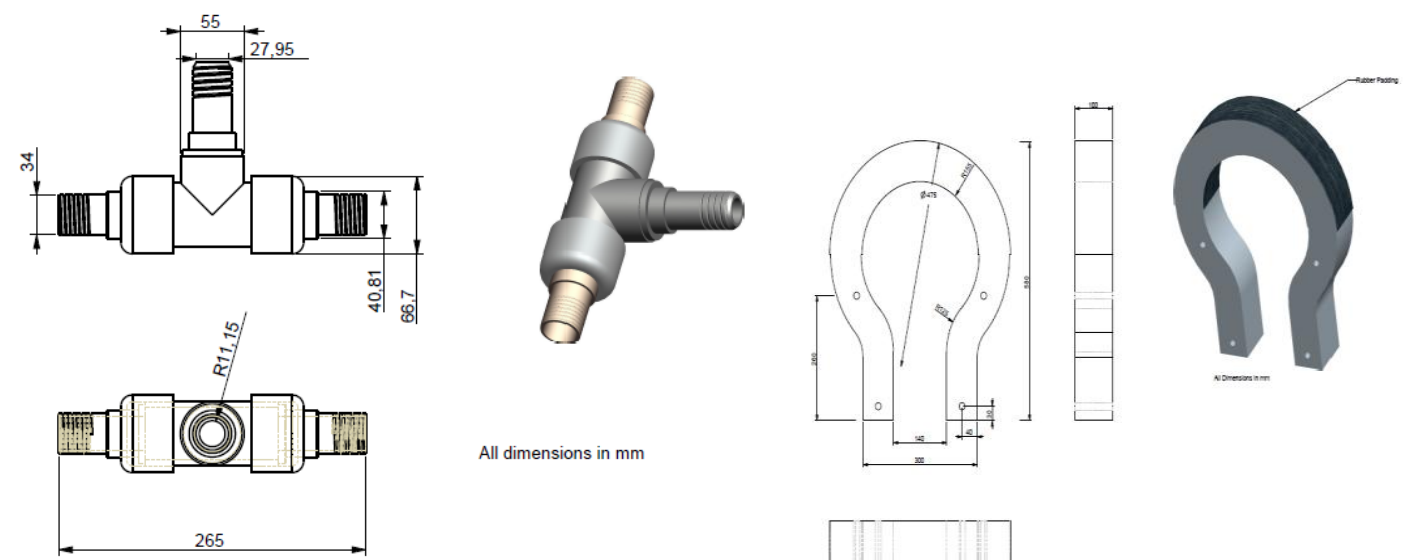
Fig.3 Relationship between oxygen consumption and different levels of draught at $17^{\circ} \mathrm{C}$ and $45 \%$ humidity and $1.5 \mathrm{~km} / \mathrm{h}$ speed of treadmill with $0^{\circ}$ and $5^{\circ}$ inclination from horizontal.
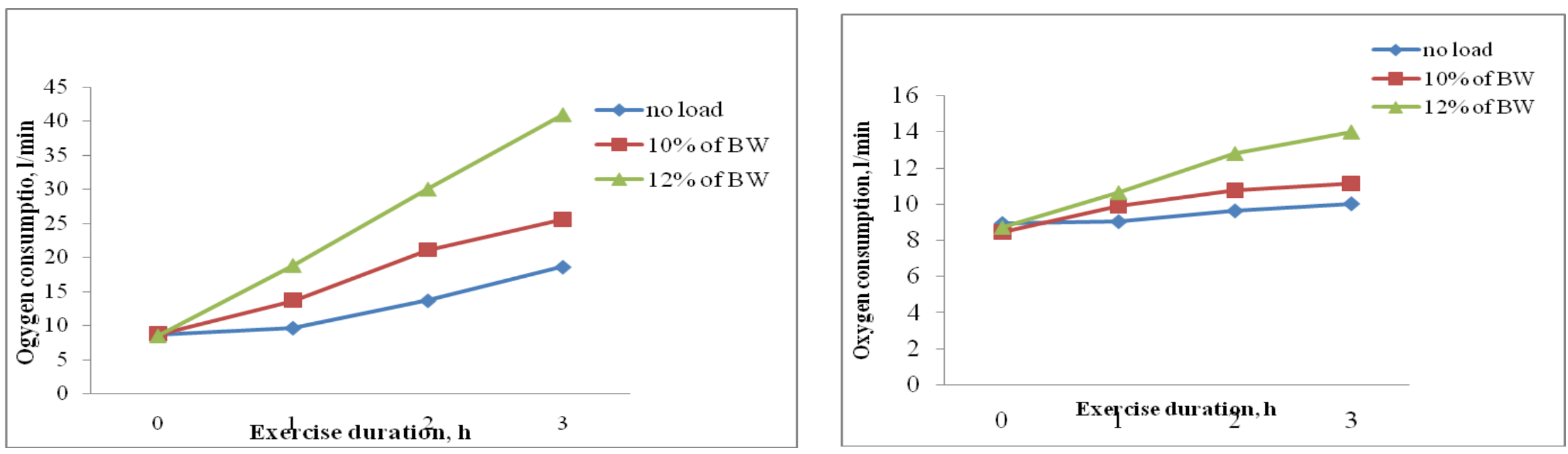

Fig.4 Relationship between oxygen consumption and different levels of draught at $17^{\circ} \mathrm{C}$ and $45 \%$ humidity and $2.5 \mathrm{~km} / \mathrm{h}$ speed of treadmill with $0^{\circ}$ and $5^{\circ}$ inclination from horizontal
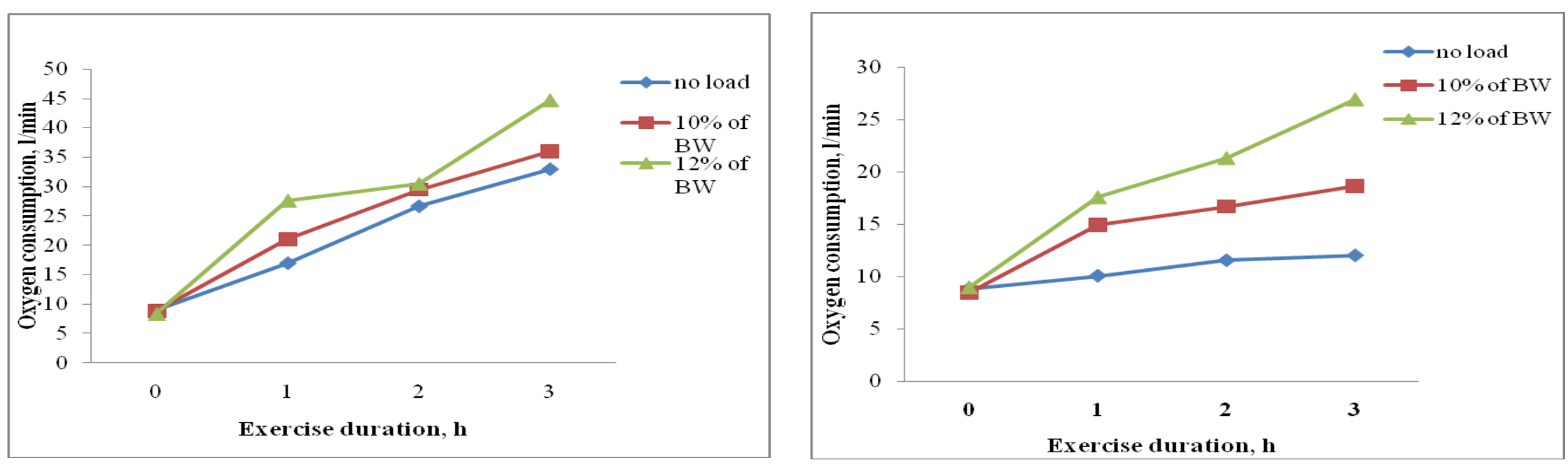
Fig.5 Variation in the average methane emission of he-buffalo during exercise in various levels of independent parameters

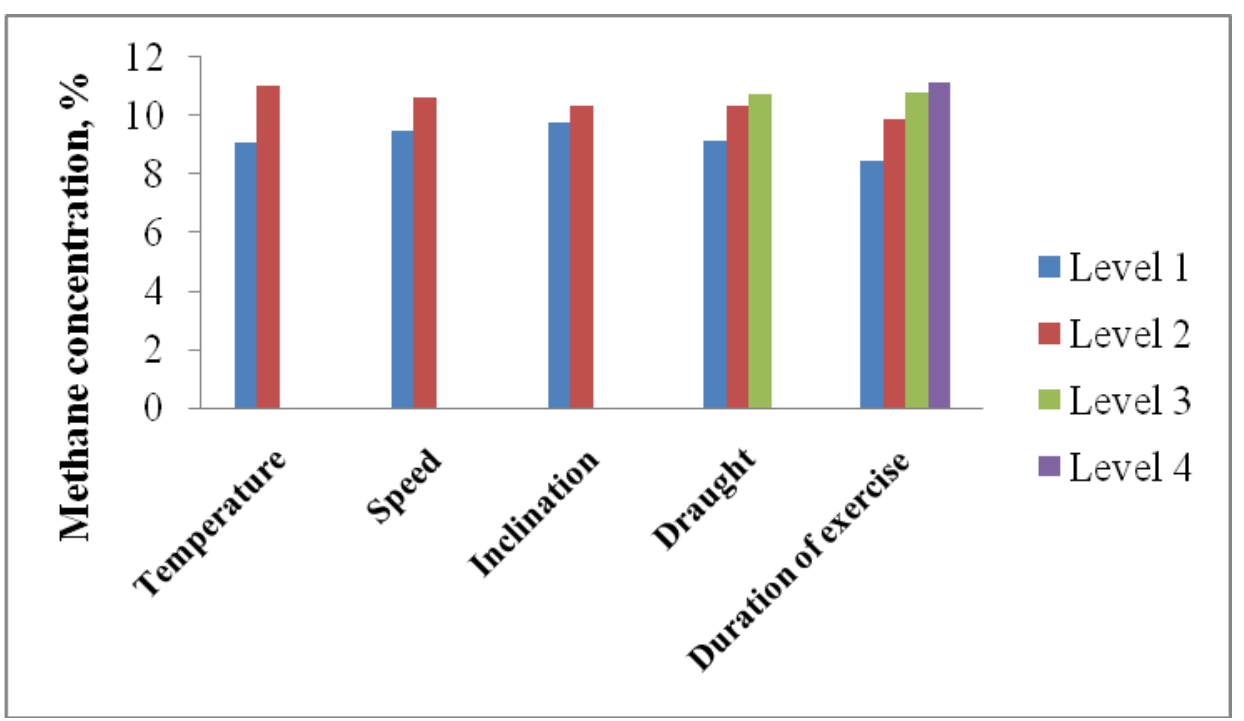

Fig.6 Variation in the average carbon dioxide concentration in exiled gas from he-buffalo during exercise in various levels of independent parameters

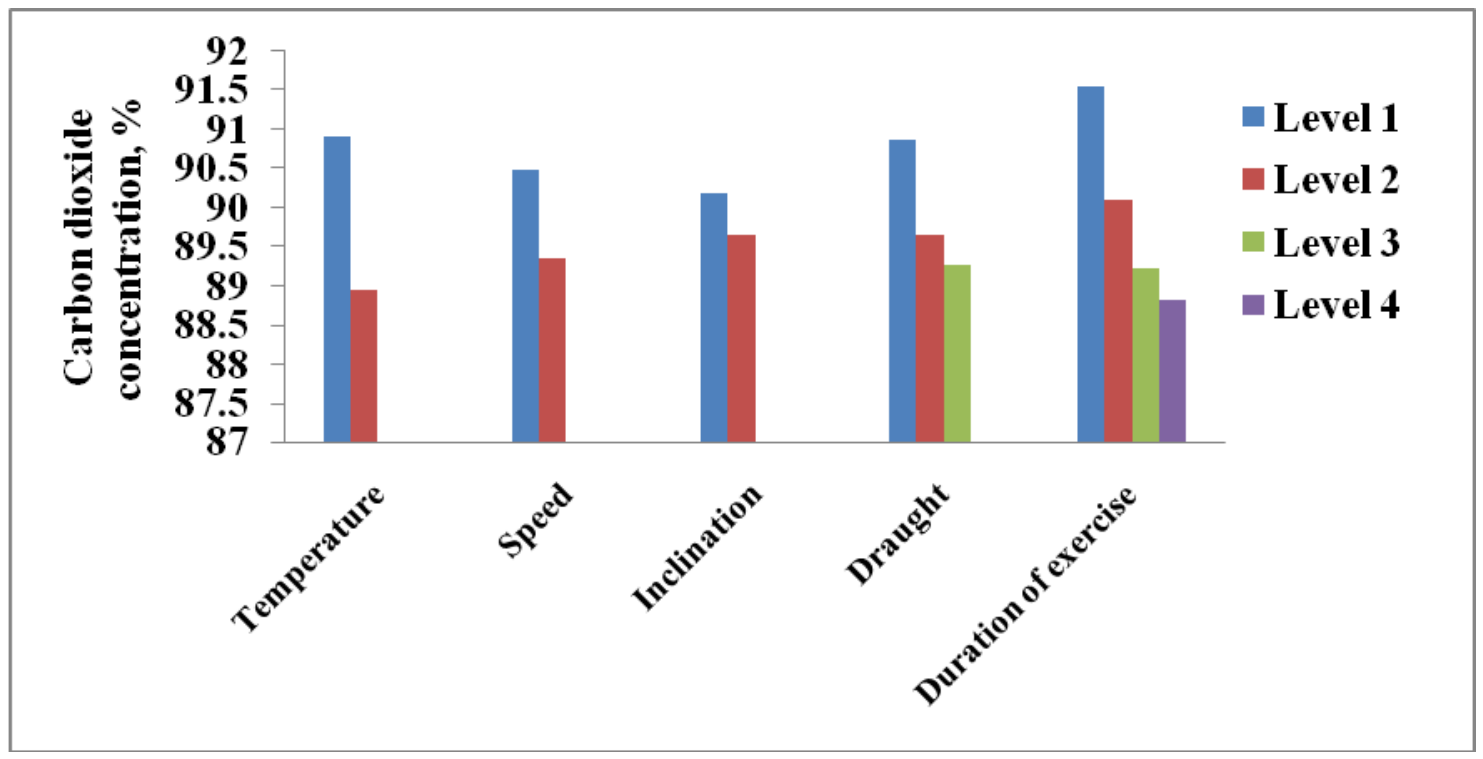

The methane emission was found to be increased from its initial value to $15.93,28.74$ and $32.68 \%$ after $3 \mathrm{~h}$ of exercise for 0 (no load), 10 and $12 \%$ draught, respectively at speed of $2.5 \mathrm{~km} / \mathrm{h}$ and $0^{\circ}$ inclination of treadmill and $37^{\circ} \mathrm{C}$ temperature and $45 \%$ humidity. The methane emission from buffalo while exercising on treadmill with $5^{\circ}$ inclination at $37^{\circ} \mathrm{C}$ temperature and $45 \%$ humidity with speed of $2.5 \mathrm{~km} / \mathrm{h}$ were observed to be increased from its initial value to $26.24,25.43$ and $29.53 \%$ for no load condition, 10 and $12 \%$ draught, respectively at the end of $3 \mathrm{~h}$ of exercise. The maximum percentage of methane in the exiled gas in the present study was $12.72 \%$ which was slightly 
higher than that of dairy cattle which was $11 \%$ according to Leng et al., (2012) (Figs. 4 and 5).

Effect of influencing factors on concentration of carbon dioxide in exiled gas of he-buffalo

The collected exiled gas were analyzed for temperatures, speeds, inclinations of treadmill, draughts, duration of exercise with flame ionization detector of gas chromatograph. The hourly estimates of carbon dioxide concentration in the exiled gas with replications for 3 hour treadmill exercises have been shown in table 4 and 5 .

\section{Statistical analysis of methane concentration in exiled gas}

Analysis of variance for effect of treatment variables as linear term and interactive term on methane emission is shown in Table C. Fvalue (82.7) indicated that the linear terms of independent variables significantly affected methane concentration $(\mathrm{p}<0.01)$ at $1 \%$ level of significance. The interactive terms also affected the methane emissions at $10 \%$ level of significance $(p<0.10)$.

F-value for individual independent variable is reported in Table D. It was found that the effect of temperature, speed, inclination, draught and duration of exercise was highly significant at $1 \%$ level of significance $(p<0.0001)$.

\section{Statistical analysis of carbon dioxide in exiled gas}

Analysis of variance for effect influencing variables as linear terms and interactive terms on carbon dioxide emission is shown in Table E. F- value (75.18) indicated that the linear terms of independent variables significantly affected carbon dioxide concentration $(\mathrm{p}<0.01)$ at $1 \%$ level of significance. The interactive terms also affected the carbon dioxide emissions at $10 \%$ level of significance $(\mathrm{p}<0.10)$.

Table $\mathrm{F}$ shows the F-value for individual independent variables. It was found that the effect of temperature, speed, inclination, draught and duration of exercise was highly significant at $1 \%$ level of significance $(\mathrm{p}<0.0001)$.

One of the most utilized, easily available and efficient source of renewable energy is draught animal power. The viability and technological economic feasibility is well within the reach of small and marginal farmers. Livestock plays a key role in food production for the millennia. Livestock production also contributes to climate change, when the greenhouse gases like methane, nitrous oxide and carbon dioxide are produced and released into the atmosphere. Although, livestock are important in agriculture, food production and economic development, the emissions of methane and carbon dioxide to total greenhouse gas emissions is significant.

On the basis of experiment, it is concluded that the oxygen consumption and methane concentration present in the exiled gas showed increasing trend with increase in duration of exercise, speed of treadmill, inclination of treadmill with horizontal and environment temperature. Whereas, the concentration of carbon dioxide present in the exiled gas showed decreasing trend with increase in duration of exercise, speed of treadmill, inclination of treadmill with horizontal and environment temperature

\section{References}

$19^{\text {th }}$ Livestock census-All India Report 2012.Ministry of Agriculture, 
Department of Animal Husbandry and Fisheries.

Agarwal A. and Upadhyay, R. C. $1997 \mathrm{~b}$. Physiological reactions and acid-base equilibrium in cross-bred (Holstein $\times$ Tharparkar) cattle in response to treadmill exercise. Draught Animal News, 26: 16-19.

Bhatta, R., Enishi, O. and Kurihara, M. 2007.Measurement of methane production. Asian Australian Journal of Animal Science, 20(8): 1305-1318.

Chhabra, A., Manjunath, K. R., Panigrahy, S. and Parihar, J. S. 2009. Spatial pattern of methane emissions from Indian livestock. Current Science, 96(5): 683689.

Christopherson, R. J. and Webster, J. F. 1971. Changes during eating in oxygen consumption, cardiac function and body fluids of sheep. Journal of Physiology,221: 441-457.

Cottle, D. J., Nolan, J. V. and Wiedemann, S.G. 2011. Ruminant enteric methane mitigation: a review. Animal Production Science, 51: 491-514.

Das, S. K., Upadhayay, R. C. and Madan, M. L. 1999. Heat stress in murrah buffalo calves. Livestock Production Science, 61: 71-78.

Grainger, C. and Beauchemin, K. A. 2011. Can enteric methane emissions from ruminants be lowered without lowering their production?.Animal Feed Science and Technology, 166-167: 308-320.

Grainger, C., Clarke, T., McGinn, S. M., Auldist, M. J., Beauchemin, K. A., Hannah, M. C., Waghorn, G. C., Clarke, H. and Eckard R. J. 2007. Methane emissions from dairy cows measured using the sulfur hexafluoride (SF6) traces and chamber techniques. Journal of Dairy Science, 90: 2755-2766.

Gworgwor, Z. A., Mbahi, T. F. and Yakubu, B. 2006.Environmental Implications of Methane Production by Ruminants: A review. Journal of Sustainable Development in Agriculture and Environment, 2(1): 0794-8896.

Harper, L.A., Denmead, O.T., Freney, J.R. and Byers, F.M. 1999.Direct measurements of methane emissions from grazing and feedlot cattle. Journal of Animal Science, 77: 1392-1401.

Howden, S. M. and P. J. Reyenga. 1999. Methane emissions from Australian livestock: implications of the Kyoto Protocol. Autralian Journal of Agriculture Research.50: 1285-1291.

India. Ministry of Environment and Forests. Second National Communication to the United Nations Framework Convention on Climate Change 2004 Report. New Delhi, Government of India. 250p.

International Panel on Climate Change (IPCC) (2006).IPCC guidelines (2006) for national greenhouse gas inventories (Volume 4). Institute for global environmental strategies, Hamyama, Japan.

Johnson, K. A. and Johnson, D. E. 1995. Methane Emission from Cattle. Journal of Animal Science, 73: 24832492.

Kapoor, R. and Upadhyay, R. C. 1993. Physiological responses an acid-base status of rural working buffaloes. Indian Journal of Dairy Science, 46 (5): 227229.

Kinsman, R., Sauer, F. D., Jackson, H. A. and Wolynetz, M. S. 1995. Methane and carbon dioxide emissions from dairy cows in full lactation monitored over a six-month period. Journal of Dairy Science, 78: 2760-2766.

Knapp, J. R., Laur, G. L., Vadas, P. A., Weiss, W. P. and Tricario, J. M. 2014. Enteric methane in dairy cattle production: quantifying the opportunity and impact of reducing emissions. Journal of Dairy Science, 97 (6): 32313261. 
Leng, R. A., Inthapanya, S and Preston, T. R. 2012.Methane production is reduced in an in vitro incubation when the rumen fluid is taken from cattle that previously received biochar in their diet. Livestock Research for Rural Development, 24 (11): 64-69.

Moss, A. R., Jean-Pierre, J. and John, N. 2000. Methane production by ruminants; It's contribution to global warming. Annales de Zootechnie, 49: 231-253.

Patra, A. K. 2012. Enteric methane mitigation technologies for ruminant livestock: a synthesis of current research and future directions. Environmental Monitoring and Assessment, 184: 1959-1952.

Patra, A.K. 2014. Prediction of enteric methane emission from buffaloes using statistical models. Agriculture, Ecosystems and Environment, 195: 139148.

Perry, B. and Sones, K. 2007. Poverty reduction through animal
health.Science, 315: 333-334.

Shibata, M. and Terada, F. 2010. Factors affecting methane production and mitigation in ruminants. Animal Science Journal,81(1): 2-10.

Swamy, M. and Bhattacharya, S. 2006.Budgeting anthropogenic greenhouse gas emission from India livestock using country-specific coefficients. Current Science, 91(10): 1340-1353.

Upadhyay, R. C. and Agarwal, A. 1997.Pulmonary and skin evaporative heat loss during exercise in hot dry conditions in crossbreds. Indian Journal of Dairy Science, 40 (1): 28-31.

Vlaming, J. B. 2008. Quantifying variation in estimated methane emission from ruminants using the $\mathrm{SF}_{6}$ tracer technique. Thesis, PhD. Massey University, Palmerston North, New Zealand.

\section{How to cite this article:}

Anvesha, Pramod Kumar and Deepak Kumar. 2017. Effect of Various Parameters on Methane Emission from the Rumen of HE-Buffalo. Int.J.Curr.Microbiol.App.Sci. 6(11): 2030-2044. doi: https://doi.org/10.20546/ijcmas.2017.611.242 